\title{
Immunologic Studies of Arginase in Tissues of Normal Human Adult and Arginase-Deficient Patients
}

\author{
E. B. SPECTOR, ${ }^{(2)}$ S. C. H. RICE, AND S. D. CEDERBAUM \\ Departments of Pediatrics and Psychiatry and The Mental Retardation Research Center, UCLA Center for the \\ Health Sciences, Los Angeles, California, USA
}

\section{Summary}

Rabbit antibody to human liver arginase was used to examine the immunologic characteristics of arginase in red blood cells (RBC), liver, kidney, brain, and gastrointestinal tract from normal adults and from patients with hyperargininemia. Greater than $90 \%$ of the arginase in $\mathrm{RBC}$ and liver was precipitated by this antibody whereas only $50 \%$ of the arginase in kidney, brain, and gastrointestinal tract reacted with it.

Two siblings and a third patient with hyperargininemia were found to have immunoreactive arginase protein in their RBC that was enzymatically inactive. The amount of arginase protein approximated that found in $\mathrm{RBC}$ from normal individuals.

A kidney biopsy obtained from one of the patients with hyperargininemia had arginase activity 4-5-fold greater than that found in normal kidney biopsy material. Double immunodiffusion and precipitation-inhibition studies demonstrated two types of arginase protein in this patient's kidney: one enzymatically inactive and precipitated by the antibody, and one enzymatically active but not precipitated by the antibody. These data, in conjunction with biochemical data reported previously demonstrate that there are two gene loci determining arginase in man.

\section{Abbreviations}

BSA, bovine serum albumin

CRM, cross-reacting material

GARGG, goat anti-rabbit gamma globulin

GI, gastrointestinal tract

$\mathrm{Hb}$, hemoglobin

PBS, phosphate buffered saline

RBC, red blood cell

Arginase (L-arginine ureahydrolase; E.C. 3.5.3.1), the last enzyme of the urea cycle, catalyzes the cleavage of arginine to ornithine and urea. It has been reported deficient in ten patients who have a characteristic clinical syndrome and elevated plasma levels of arginine $(2,3,7,11,12,16,17)$. Despite the fact that they have less than $2 \%$ of normal liver arginase activity $(3,7)$, the patients excrete low-to-near-normal quantities of urea $(2,3$, $7,11,12,16,17)$. The capacity to synthesize urea may be due to residual enzyme activity, to an alternate pathway for urea synthesis, or to a second structural gene locus determining arginase (10). Todeeide among these alternative hypotheses we previously studied kinetic and physicochemical properties of the arginases in RBC, liver, kidney, Gl, and brain from normal human adults and fetuses $(13,14)$. These studies failed to either prove or exclude any of these hypotheses.

We now report the immunochemical properties of arginase from normal humans and from three patients with arginase deficiency. These studies strongly support the existence of two structural gene loci determining arginase in man.

\section{MATERIALS AND METHODS}

Materials. Arginine: and buffers were obtained from Sigma Chemical Company, St. Louis, MO, and were of the highest grade available. Guanido $\left[{ }^{14} \mathrm{C}\right]$ arginine $(53 \mu \mathrm{Ci} / \mu$ mole $)$ was obtained from Amersham-Searle, Chicago, IL. GARGG was obtained from CalBiochem/Behring.

Tissue extracts. Tissues were obtained at the time of autopsy or biopsy. They were homogenized in 2-3 volumes of $0.01 \mathrm{M}$ Tris- $\mathrm{HCl}$, pH 7.4 using a Polytron. The homogenates were centrifuged at $30,000 \times g$ for $60 \mathrm{~min}$ and the resulting supernatants used in these studies.

Enzyme assay. Our modification of the radiochemical method of Schimke (8) was used to determine arginase activity (13). It is linear with respect to time and protein concentration in the ranges used in these studies (13). A unit of enzyme activity is defined as $1 \mu$ mole arginine cleaved per $30 \mathrm{~min}$.

Preparation of antibodies. Rabbit antibody raised against purified rat liver arginase was received as a gift from Dr. Raphael Palacios, Institute of Biomedical Investigation at the Autonomous University of Mexico, Mexico City, Mexico (15). This antibody precipitated both rat and human liver arginase activity completely, the latter with lower affinity. The antibody formed a single, very faint immunoprecipitation band when tested with the liver extract from an arginase deficient patient, R.U. (Fig. 1A). The band was identical with a much stronger one seen in normal liver extract, confirming the monospecificity of this antibody toward arginase. Because normal amounts of enzyme protein were found in the patient's red blood cells with antihuman liver arginase, we infer that the absence of easily visible CRM in this study was due to the use of the anti-rat liver antibody and a less fresh specimen. The data are presented only to confirm the specificity of the antibody.

Rabbit anti-human liver arginase was raised in our laboratory. Arginase was isolated from human liver obtained at the time of kidney transplant. It was purified 500 -fold by the method of Schimke.(9). The purified enzyme was incubated with anti-rat liver arginase antibody at $37^{\circ} \mathrm{C}$ for $30 \mathrm{~min}$ and $4^{\circ} \mathrm{C}$ overnight. The antigen-antibody complex was removed by centrifugation at $30,000 \times g$ for $30 \mathrm{~min}$ and was resuspended in $0.01 \mathrm{M}$ Tris$\mathrm{HCl}, \mathrm{pH} 7.4$. Sodium dodecyl sulfate polyacrylamide gel electrophoresis of this complex demonstrated three bands: two bands corresponding to the light and heavy chains of $\operatorname{Ig} G$ and one band corresponding to the arginase monomer. The antibody used in this study was raised against this antigen-antibody complex in a female New Zealand white rabbit by standard means.

An IgG-rich fraction from the serum was isolated by precipitation with ammonium sulfate $(30 \%)$, resuspension in $1 / 5$ volume 

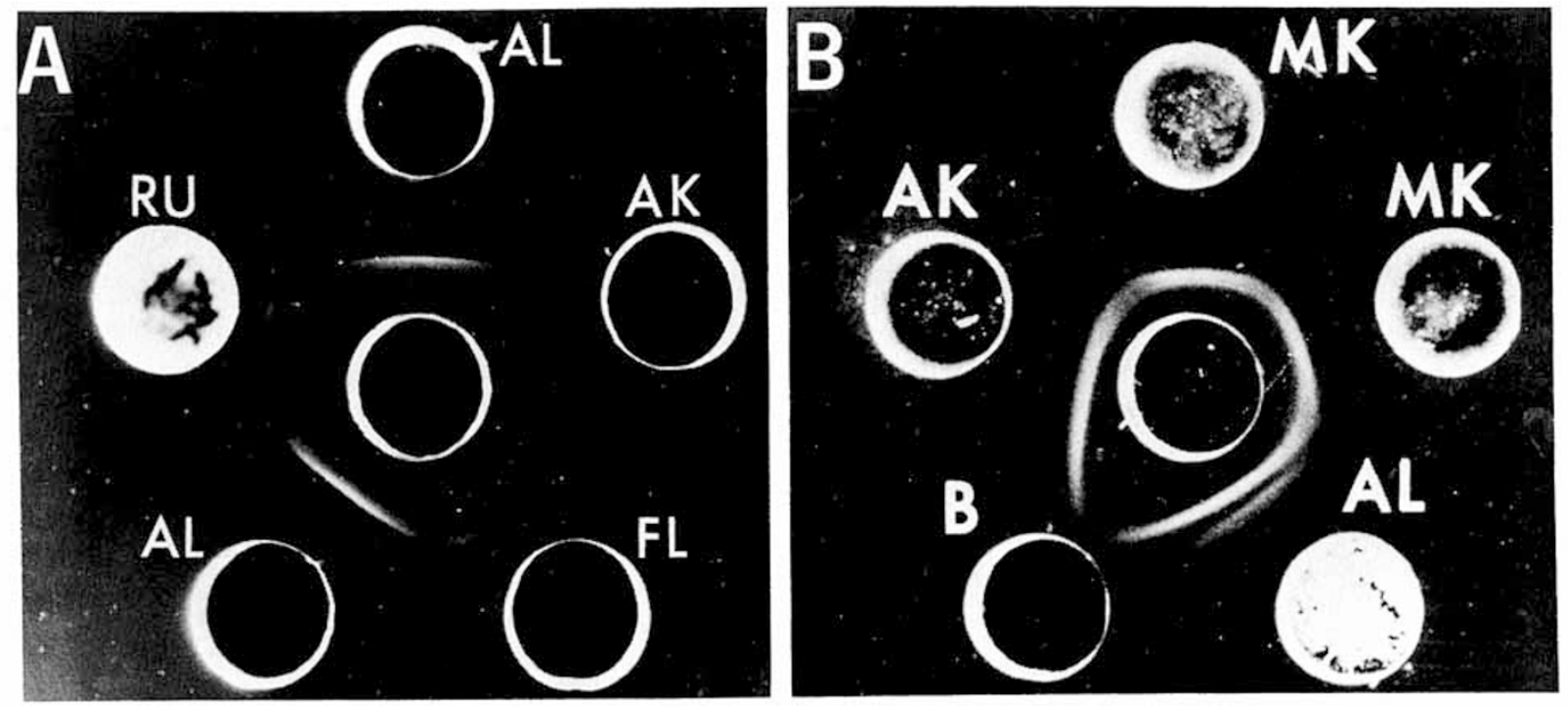

Fig. 1. Ouchterlony double immunodiffusion studies of human arginase $(A)$ Rabbit anti-rat liver arginase serum is in the center well. Tissue extracts are in the surrounding wells: AL, adult liver; AK, adult kidney; FL, fetal liver; and RU, liver from patient R.U. (B) Rabbit anti-human liver arginase antibody is in the center well. Tissue extracts are in the surrounding wells: MK, kidney from patient M.U.; AL, adult liver; AK, adult kidney; and $\mathrm{B}$, buffer. Diffusion proceeded for $18 \mathrm{~h}$ at $22^{\circ} \mathrm{C}$ before the plates were photographed in each experiment. The protein concentrations of each well were approximately equal.

$0.01 \mathrm{M}$ Tris- $\mathrm{HCl}, \mathrm{pH} \mathrm{7.4,} \mathrm{and} \mathrm{dialysis} \mathrm{against} \mathrm{this} \mathrm{buffer.} \mathrm{A}$ similar fraction was isolated from serum obtained from a rabbit that was not immunized and was designated "control" immunoglobulin. These IgG-rich fractions were utilized in all experiments except Ouchterlony double immunodiffusion.

Protein determination. Protein concentration was determined by the method of Bradford (1). BSA was used as a standard. Coomassie blue dye reagent was obtained from Bio-Rad Laboratories.

Immunoprecipitation of arginase in tissue extracts. Immunoprecipitation experiments were carried out as described previously for RBC (13). Tissue extracts were used directly or diluted in $0.01 \mathrm{M}$ Tris- $\mathrm{HCl}, \mathrm{pH} 7.4$, to a final activity of $0.2-5.0 \mathrm{U}$ of arginase activity per $50 \mu \mathrm{l}$. Extracts were incubated with varying amounts of anti-arginase $(0-320 \mu \mathrm{g})$ and control immunoglobulin, in a constant final volume, for $30 \mathrm{~min}$ at $37^{\circ} \mathrm{C}$ and overnight at $4^{\circ} \mathrm{C}$. The final concentration of immunoglobulin (anti-arginase plus control) was approximately $320 \mu \mathrm{g}$. The immunoglobulin was precipitated by adding GARGG and incubating the mixtures for 4 more $\mathrm{h}$ at $4^{\circ} \mathrm{C}$. The antigen-antibody complexes were collected by centrifugation at $30,000 \times g$ for $30 \mathrm{~min}$ at $4^{\circ} \mathrm{C}$. The arginase activity remaining in $50-\mu 1$ aliquots of the resulting supernatants was determined. Triplicate determinations on each supernatant of arginase activity in this and other experiments did not vary by more than $10 \%$.

Presence of $C R M$ in patient $R B C$. Rabbit anti-human liver antibody was used to detect the presence of CRM in RBC extracts of three patients, (R.U., M.U., and M.O.) two of whom were siblings, with hyperargininemia. $\mathrm{RBC}$ hemolysates were prepared from blood samples obtained from the patients and from normal individuals (13). The RBCs from the patients had less than $1 \%$ of the arginase activity found in control $\mathrm{RBC}[<5 \mathrm{U} / \mathrm{g} \mathrm{Hb}$ versus $478.5 \pm 103 \mathrm{U} / \mathrm{g} \mathrm{Hb}(2,3)]$. The amount of hemoglobin, in each sample (control and patient) was determined (18) and the samples were diluted with PBS $(\mathrm{pH} 7.4)$ so that the hemoglobin concentration was $0.08-0.12 \mathrm{mg} / \mathrm{ml}$. The amount of anti-human liver arginase antibody needed to precipitate greater than $95 \%$ of the arginase activity in $50 \mu \mathrm{l}$ of the normal RBC hemolysates was determined (approximately 6-12 $\mu \mathrm{g}$, depending upon the sample) as described for the tissue extracts. The RBC hemolysate from the normal individuals was diluted into half with PBS plus BSA $(0.1 \mathrm{mg} / \mathrm{ml}$ of PBS) or RBC hemolysate from a patient.
The diluted extracts $(5-100 \mu \mathrm{l})$ were incubated with anti-human liver arginase antibody $(6-12 \mu \mathrm{g})$. Incubations and arginase assay were carried out as described above and the amount of normal $\mathrm{RBC}$ extract diluted with either PBS or patient hemolysate needed to begin to displace enzymatically active protein from the antigen-antibody complex into the supernatant determined. Absorption studies in liver and kidney. Kidney extract (12.4 U) was incubated with enough anti-human liver arginase antibody $(2.7 \mathrm{mg})$ to complex $50 \%$ of the kidney arginase activity after incubation at $37^{\circ} \mathrm{C}$ for $30 \mathrm{~min}$ and $4^{\circ} \mathrm{C}$ overnight. The antigen-antibody complex was removed by centrifugation and one-half $(1 \mathrm{ml})$ of the supernatant was removed $(\mathrm{Sl})$ for further examination. The remaining supernatant was incubated with 6.5 $\mathrm{U}$ of kidney arginase and treated as in the first step. One $\mathrm{ml}$ of this second supernatant was removed (S2) and the remaining supernatant was incubated for a third time with $6.5 \mathrm{U}$ of kidney arginase yielding a third supernatant (S3). A parallel experiment was carried out in which control immunoglobulin was used instead of anti-human liver arginase antibody. The supernatants from each precipitation were then tested for the presence of antibody that reacted with human liver arginase. In parallel tubes, $0-100 \mu$ l of the three supernatants and either anti-human liver arginase antibody or control immunoglobulin was incubated with $7.2 \mathrm{U}$ of human liver arginase and immunoprecipitation studies were carried out as described above.

Kidney biopsy. An open kidney biopsy was performed on patient M.U. at the time of therapeutic orthopedic surgery. This procedure and the liver biopsy performed on R.U. were approved explicitly by the Human Subject Protection Committee at UCLA and performed with informed parental consent. Tissue, $0.26 \mathrm{~g}$, was obtained and homogenized in $3.0 \mathrm{ml}$ of $0.01 \mathrm{M}$ Tris- $\mathrm{HCl}$, $\mathrm{pH}$ 7.4. The extract was centrifuged at $30,000 \times g$ for $60 \mathrm{~min}$ at $4^{\circ} \mathrm{C}$ and the arginase activity in the supernatant determined. The pellet was extracted a second time in an identical manner. Aliquots of this kidney extract ( $35 \mathrm{mU}$ arginase activity) were incubated with anti-human liver arginase antibody $(0-33 \mu \mathrm{g})$ as described above. The amount of arginase activity remaining in $50 \mu \mathrm{l}$ of the final supernatant was determined.

Increasing amounts of kidney extract (43-324 mU arginase activity) were added to $188 \mathrm{mU}$ of liver arginase activity in the presence of enough antibody to precipitate $94 \%$ of the liver arginase activity. The extracts were incubated as described above 
and the amount of arginase in $50 \mu \mathrm{l}$ of the final supernatant determined. The amount of arginase activity contributed by the kidney extract was subtracted from the total activity found in the final supernatant.

\section{RESULTS}

Immunoprecipitation studies in normal tissue. Quantitative immunoprecipitation studies with rabbit anti-human liver arginase antibody were performed using extracts of normal adult tissue (Fig. $2 \mathrm{~A}$ and $2 \mathrm{~B}$ ). The antibody precipitated $90 \%$ or more of the arginase activity in RBC and liver extracts with 12.8 and $11.1 \mathrm{U}$ of arginase activity precipitated per $\mathrm{mg}$ antibody (IgG rich), respectively. Biphasic precipitation profiles were obtained for kidney, GI, and brain. The first portion was similar to that for liver and RBC with 9.4, 8.9, and $3.5 \mathrm{U}$ of arginase activity precipitated per mg antibody (IgG rich), respectively. Approximately $50 \%$ of the activity in each tissue was not precipitated, even when a 10 -fold excess of antibody was added.

Presence of CRM in the red blood cells of arginase deficient patients. RBC extracts from three patients demonstrated CRM in amounts equal to that found in normal individuals when tested with rabbit anti-human liver arginase antibody (Fig 3A and 3B). The amount of normal extract with PBS plus BSA added needed to begin displacement of arginase activity into the supernatant (the $\mathrm{x}$-intercept in Fig. 3A and 3B) was 2.2, 1.4, and 2.0 times greater than that when an equal volume of extract from each of the three patients was added (R.U., M.U., and M.O., respectively). Studies repeated in the opposite manner with the normal enzyme held constant and the mutant extract added in varying amounts gave essentially identical results (data not shown).

Absorption studies. Kidney extract from a normal donor was able to neutralize all of the antibody to human liver arginase after a series of three absorptions. The three supernatants ( $\mathrm{S}$, S2, S3) precipitated progressively less liver arginase activity until after the third, no liver arginase activity was precipitated (data not shown).

Immunologic and biochemical studies of kidney from an arginase-deficient patient. Kidney extract from patient M.U. had a specific activity of $64 \mathrm{mU}$ arginase activity per $\mathrm{mg}$ protein as compared to 6-12 mU arginase activity per $\mathrm{mg}$ protein in normal adult and fetal biopsy or autopsy material (14). The patient extract demonstrated a broad line of identity with normal adult liver and kidney on double immunodiffusion using anti-human liver arginase antibody but lacked, along with normal kidney, a

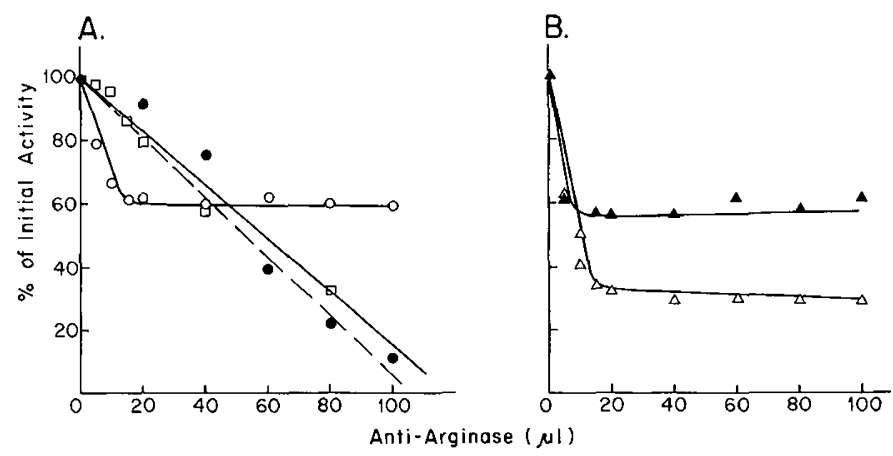

Fig. 2. Reaction of anti-human liver arginase antibody with arginase from liver, red blood cells, gastrointestinal tract, and brain. Tissue extracts $(30,000 \times g)$ were incubated with increasing amounts of antihuman liver arginase antibody $(0-320 \mu \mathrm{g})$ as described in "Materials and Methods." $(A)$ Human liver $(-100 \%=5.1 \mathrm{U}$; red blood cells $(\square-\square), 100 \%=4.1 \mathrm{U}$; and kidney $(\mathrm{O}-\mathrm{O}), 100 \%=1.07 \mathrm{U} .(B)$ gastrointestinal tract $(\Delta-\Delta), 100=0.57 \mathrm{U}$. and brain $(\mathbf{\Delta}-\mathbf{\Delta}), 100$ $=0.23 \mathrm{U}$. Each point represents the average of triplicate determinations from one experiment. Each tissue was tested at least two times.

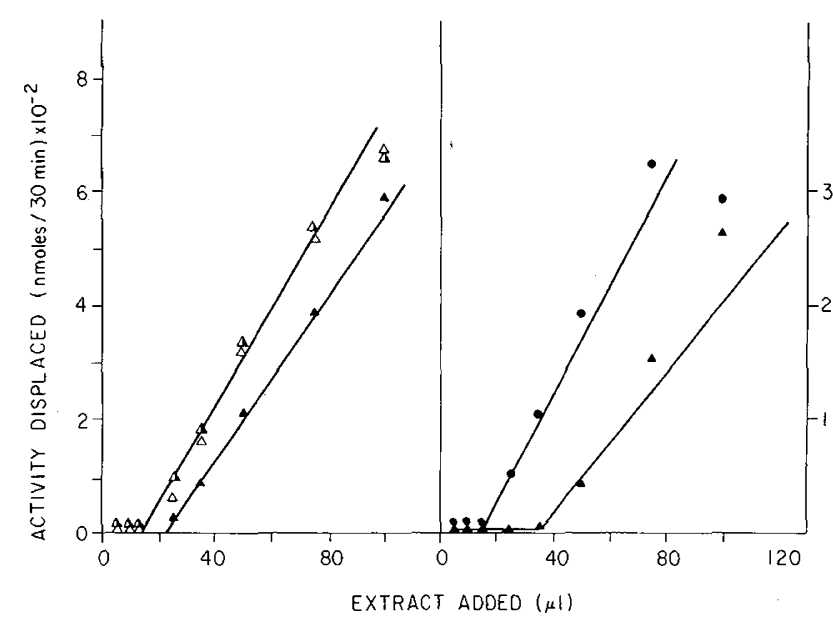

Fig. 3. Presence of cross-reacting material in red blood cell (RBC) hemolysates of three patients with hyperargininemia. RBC hemolysate from a normal individual $(100-700 \mathrm{mU})$ was diluted with phosphate buffered saline (PBS) plus bovine serum albumin $(0.1 \mathrm{mg} / \mathrm{ml}), \mathrm{pH} 7.4$ $(\boldsymbol{\Lambda}-\mathbf{\Lambda}$, left and right hand panels) or with RBC hemolysate from patients R.U.( $\mathbf{\Delta}-\mathbf{\Delta}$, left hand panel), M.U. ( $\Delta-\Delta$, left hand panel), and M.O. (- right hand panel). These mixtures were incubated with enough antibody (12 $\mu \mathrm{g}$ in left hand panel or $6 \mu \mathrm{g}$ in right hand panel) to precipitate greater than $95 \%$ of the arginase activity in $50 \mu \mathrm{l}$ of the normal RBC hemolysate. In panel right hand panel the control RBC hemolysate was diluted 1:1 with PBS so that the hemoglobin concentration in the control and patient sample was similar. Diluted extract (5$100 \mu \mathrm{l}$ ) was incubated with the antibody and immunoprecipitation carried out as described in "Materials and Methods." Each point represents the average of triplicate determinations from one experiment. Each sample was tested at least two times.

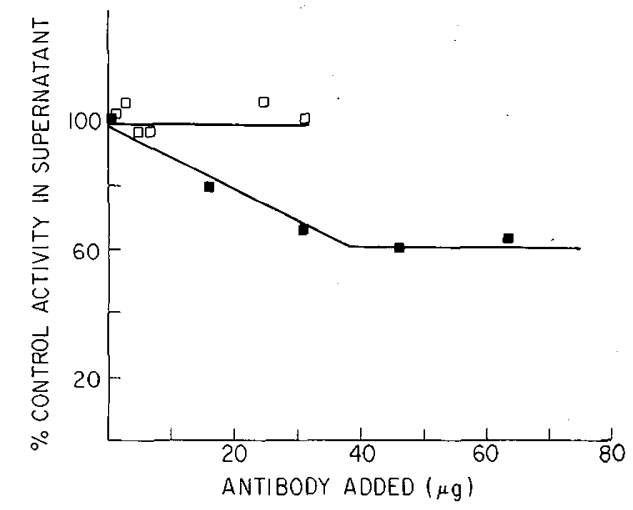

Fig. 4. Reaction of normal kidney arginase and patient M.U. kidney arginase with anti-human liver arginase antibody. Extracts from normal kidney $(\square-\square, 736 \mathrm{mU})$ and from M.U. kidney $(\square-\square, 375 \mathrm{mU})$ were incubated with increasing amounts of anti-human liver arginase antibody (0-65 $\mu \mathrm{g}$ and $0-33 \mu \mathrm{g}$, respectively) as described in "Materials and Methods." Each point represents the average of triplicate determinations. The control kidney was tested three times and M.U. kidney one time.

small band found in normal liver (Fig. 1B); however, none of the enzyme activity in M.U.'s kidney extract was precipitated by rabbit anti-human liver arginase antibody over a 30-fold range of added antibody (Fig. 4). This same amount of antibody precipitated $50 \%$ of a similar amount of normal kidney arginase activity (Fig. 4). The presence of an arginase protein that was enzymatically inactive, but immunologically reactive was also demonstrated in the patient's extract. Normal liver extract was mixed with enough anti-human liver arginase antibody to precipitate $94 \%$ of the liver activity. When increasing amounts of 


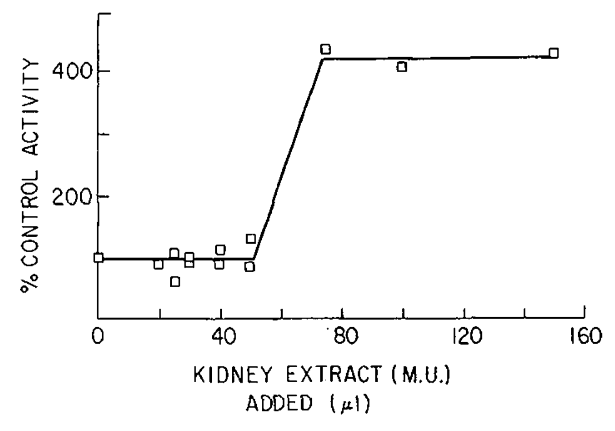

Fig. 5. Presence of cross-reacting material in kidney of patient M.U. Extract from normal liver (188 $\mathrm{mU})$ was incubated with enough antihuman liver arginase antibody to precipitate $94 \%$ of the liver arginase activity. Increasing amounts of kidney extract from patient M.U. 43$324 \mathrm{mU}$ ) were added to this mixture. Immunoprecipitation and arginase assays were performed as described in "Materials and Methods." Each point represents the average of triplicate determinations in three separate experiments. All of the data points are represented on the graph.

patient kidney extract were added to this mixture, liver arginase was displaced from the antigen-antibody complex (Fig. 5). The abrupt alteration of the plateau was unexpected, although we tried to cover this area by varying the amount of patient kidney extract added.

\section{DISCUSSION}

Our previous studies of the properties of normal adult and fetal RBC and liver suggested that a single structural gene locus specifies arginase activity $(13,14)$. Studies in arginase deficiency, in which virtually no residual activity is seen in liver, RBC, white blood cells, and the stratum corneum of the skin buttressed this conclusion $(2,3,7,11,12,16,17)$. Previous electrophoretic (14) and now immunologic studies of kidney, brain, and GI reveal a second form of arginase that differs in net charge and immunoreactivity from that found in liver. These data on normal human tissue failed, however, to demonstrate whether these differences were due to a second arginase locus or to post-translational modification of the product of a single locus. Herzfeld and Raper (5) have demonstrated these same two forms of arginase in rat tissues, but could not distinguish between the one and two locus hypotheses.

An open kidney biopsy of arginase-deficient patient M.U. allowed us to examine the biochemical and immunologic activity of arginase. The specific activity of the patient extract was 4-5 times that found in either biopsy or autopsy kidney obtained from normal individuals. This enzymatically active protein did not cross-react with anti-human liver arginase antibody. An enzymatically inactive protein, cross-reacting with anti-human liver arginase was also found in the biopsy material. This presumably represents the protein product of the mutant structural gene (Fig. 5).

We conclude that there are two distinct structural gene loci that encode arginase in man. One locus is expressed as the major arginase isozyme in the liver and RBC, contributing $90 \%$ or more of the arginase activity in these tissues. The enzyme activity determined by this locus is lost in our patients with hyperargininemia. This locus is also expressed in kidney, GI, and brain, and by immunoprecipitation appears to contribute approximately $50 \%$ of the arginase activity in these tissues.

The second arginase locus may be expressed to approximately the same level in all tissues. In liver and RBC, it may constitute less than $5 \%$ of the total activity and go unnoticed against the higher background, whereas in kidney, GI, and brain, it determines approximately $50 \%$ of the total tissue arginase activity. Other, far more complex explanations can be developed to explain these data, but seem unlikely. We are currently undertaking the structural studies necessary to prove this inference.

The product of the second arginase locus appears to be the only enzymatically active protein in our patients with hyperargininemia. Both proteins are being synthesized, however, as demonstrated by the normal amount of CRM to anti-liver arginase antibody present in the RBC extracts and kidney of the patients. The enzyme product of the second locus may be "induced" in the kidney of patient M.U. The total amount of active arginase in him is estimated to be equivalent to $2 \%$ of the total arginase activity present in normal liver. This residual activity may account for the relatively high urea production in hyperargininemic patients $(2,3,7,11,12,16,17)$ and may also explain the reduced vulnerability of these patients to life-threatening hyperammonemia.

The biologic reason for two arginase structural gene loci is unknown. Mezl and Knox (6) have speculated that a second form of arginase may function primarily as a source of proline for protein biosynthesis. Ornithine is also the substrate for ornithine decarboxylase, the first enzyme in the critical polyamine biosynthetic pathway and as such may require distinctly different control of its expression and cellular localization (4).

\section{REFERENCES AND NOTES}

1. Bradford $M, M$ - A rapid and sensitive method for the quantitation of microgram quantities of proteins using the principle of protein-dye binding. Anal. Biochem., 72: 248 (1976).

2. Cederbaum, S. D., Shaw, K. N. F., and Valente, M.: Hyperargininemia. J. Pediatr. 90: 569 (1977).

3. Cederbaum, S. D., Shaw, K. N. F., Spector, E. B., Verity, M. A., Snodgrass, P. J., and Sugarman, G. I.: Hyperargininemia due to arginase deficiency. Pediatr. Res., 13: 827 (1979).

4. Fruton, J. and Simmonds, S.: General Biochemistry p. 767 (Wiley, New York, 1958).

5. Herzfeld, A. and Raper, S. M.: The heterogeneity of arginases in rat tissues. Biochem. J., 153: 469 (1976)

6. Mezl, V. A. and Knox, W. E.: Metabolism of arginine in lactating mammary gland. Biochem. J., 164: 105 (1977).

7. Michels, V. V. and Beaudet, A. L.: Arginase deficiency in multiple tissues in argininemia. Clin. Genet., 13:61 (1978).

8. Schimke, R. T.: Enzymes of arginine metabolism in mammalian cell cuiture. I. Repression of argininosuccinate synthetase and argininosuccinase. J. Biol. Chem., 239: 136 (1964).

9. Schimke, R. T.: Arginase. In: Methods in Enzymology, Tabor, H. and Tabor, C. W., Eds., p. 313 (Academic Press, New York, 1970).

10. Shih, V. E.: Urea cycle disorders and other congenital hyperammonemic syndromes. In: The Metabolic Basis of Inherited Diseases, 4th ed., Stanbury, J. B., Wyngaarden, J. B., and Fredrickson, D. S., Eds., p. 362 (McGraw-Hill, New York, 1978).

11. Snyderman, S. E., Sansaricq, C., Chen, W. J., Norton, P. M., and Phaneoalkar, S. V.: Argininemia. J. Pediatr., 90: 563 (1977).

12. Snyderman, S. E., Sansaricq, C., Norton, P. M., and Goldstein, F. J.: Argininemia treated from birth. J. Pediatr., 95: 61 (1979).

13. Spector, E. B., Kiernan, M., Bernard, B., and Cederbaum, S. D.: Comparative properties of fetal and adult red blood cell arginase: $A^{\prime}$ possible prenatal diagnostic test for arginase deficiency. Am. J. Hum. Genet., 32: 79 (1980).

14. Spector, E. B., Rice, S. C. H., Moedjono, S., Bernard, B., and Cederbaum, S. D.: Biochemical properties of arginase in human aduit and fetal tissues. Biochem. Med., 28: 165 (1982).

15. Tarrab, R., Rodriguez, J., Huitron, C., Palacios, R., and Soberon, G.: Molecular forms of rat liver arginase: Isolation and characterization. Eur. J. Biochem., 49: 457 (1974).

16. Terheggen, H. G., Schwenk, A., Lowenthal, A., Van Sande, M., and Colombo, J. P.: Argininemia with arginase deficiency. Lancet 2: 748 (1969).

17. Terheggen, H. G., Lowenthal, A., Lavinha, F., and Colombo, J. P.: Familial hyperargininemia. Arch. Dis. Child., 50: 57 (1975).

18. Wintrobe, M. M., Lee, G. R., Boggs, D. R., Bithell, T. C., Athens, J. W., and Foerster, J., Eds.: Clinical Hematology, 7th ed. p. 114 (Lea and Febiger, Philadelphia, 1976).

19. We thank the Department of Pathology at UCLA for the tissue samples, Dr. Raphael Palacios for the anti-rat liver arginase antibody and Drs. James McGinnis and George Popjak for valuable advice and discussion.

20. Presented in part in abstract form: Amer. J. Hum. Genet. 32:55A (1980); Pediat. Res. 15:569 (1981).

21. Requests for reprints should be addressed to: Dr. E. B. Spector, Mental Retardation Research Center, 760 Westwood Plaza, Los Angeles, CA 90024.

22. Supported in part by the Mental Retardation Center at the UCLA Center for the Health Sciences and NIH Grants HD-11298, AM-25983, HD-05615, HD-06576, HD-04612 and RR-00865.

23. Received for publication June 8, 1982.

24. Accepted for publication November 15, 1982. 